\title{
Effect of Polyvinylpyrrolidone on Vitrification of Buffalo (Bubalus bubalis) Oocytes
}

\author{
Jannatul Bari\#, M.N. Islam, Md Hasanur Alam, A. Khatun, M.A. Hashem and M. Moniruzzaman*
}

Department of Animal Science, Bangladesh Agricultural University, Mymensingh-2202, Bangladesh

\begin{abstract}
Vitrification, a method of rapid cooling, is an alternate cryopreservation method of oocytes and embryos. The present study was aimed to examine the effect of polyvinylpyrrolidone (PVP) on vitrification of buffalo oocytes. Cumulus oocyte complexes (COCs) with fully grown oocytes (120-130 $\mu \mathrm{m}$ in diameter) were aspirated from slaughtered buffalo ovaries for vitrification. COCs were treated with equilibration solution at room temperature for 5 min and then transferred to a vitrification solution for $1 \mathrm{~min}$. Then the COCs were submerged into liquid nitrogen $\left(-196^{\circ} \mathrm{C}\right)$ for a while using cryotops. The COCs were thawed, diluted, and washed in a washing solution for $5 \mathrm{~min}$, respectively. Vitrified oocytes were incubated for in vitro maturation (IVM) at $38.5 \mathrm{C}$ under an atmosphere of $5 \% \mathrm{CO}_{2}$ in the air for 24 hrs. Cumulus cells surrounding the oocytes were removed mechanically, oocytes were fixed in acetic acid and ethanol, and stained with aceto-orcein to examine the meiotic stages of oocytes. The numbers of morphologically normal oocytes after vitrification were higher in 5\% PVP than 0 and 10\% PVP groups. A proportion of oocytes treated with $5 \%$ PVP reached the metaphase II (MII) stage while none of the oocytes from $0 \%$ and 10\% PVP groupsdeveloped beyond anaphase I and metaphase I (MI) stages, respectively. These results show that PVP can be used as a cryoprotectant for the vitrification of buffalo oocytes.
\end{abstract}

Keywords: Buffalo, cryopreservation, in vitro maturation, oocytes, PVP.

\section{INTRODUCTION}

The buffalo (Bubalus bubalis, L.) is an important livestock species in the world. Buffalo farming is highly emphasized for household income from milk for farmers' livelihood in Bangladesh [1]. Buffaloes have low reproductive performances caused by silent estrus, seasonal anestrous, delayed puberty, late post-partum conception, and a long calving interval. Buffalo oocytes collected from large antral follicles during the luteal phase are less competent due to the presence of different fatty acids in follicular fluid [2]. Due to low response to multiple ovulation and embryo transfer (MOET), in vitro embryo production (IVEP) technology is important in buffaloes. The major limitation of IVEP technology in buffalo is the small number of oocytes that can be recovered from donors. Buffalo ovary contains small numbers of antral follicles and a high percentage of atretic follicles [3]. It has been reported that buffalo ovaries have a smaller number of recruitable follicles [4] and lower reproductive hormones [5] at a given time compared to a cow. The scarcity of oocytes is a drawback for exploiting embryo technologies in buffaloes. Therefore, vitrification can be a useful technique to avail buffalo oocytes for reproductive technology.

*Address correspondence to this author at the Department of Animal Science, Bangladesh Agricultural University, Mymensingh-2202, Bangladesh; Tel: 88091-67401-6/ Ext-2620; Fax: 880-91-61510; E-mail: monir.as@bau.edu.bd

"These authors contributed equally to this work.
Vitrification, a method of rapid cooling, is the solidification of a solution at low temperatures $\left(-196^{\circ} \mathrm{C}\right)$ without ice crystal formation in the cell cytoplasm by use of a very high concentration cryoprotectants [6]. To improve the reproductive performance of water buffaloes, a method has been developed by AbdelGhani et al. for the in vitro culture of vitrified-warmed ovarian tissues [7]. They found that supplementation of vitrified-warmed ovarian tissue culture medium with growth differentiation factor-9 (GDF-9) promoted primary follicle development that might be used for improving ovarian inactivity in water buffaloes. Oocytes were collected from slaughtered water buffaloes, matured and fertilized in vitro, and embryos were cultured in cumulus cells monolayer, then resultant preimplantation stage embryos were cryopreserved and transferred to recipient buffaloes [8]. Six healthy and normal calves produced from that cryopreserved technologies indicated the potential application of vitrification techniques in buffalo reproduction regime. In the year 2005, in vitro fertilized and cryopreserved water buffalo embryos were transported from Italy to California for transferring them into recipient buffaloes [9]. In the vitrification method, a cryo-device is required to hold the sample materials and be used for submerging into liquid nitrogen. A comparative study on cryo-devices has been done by Mahesh et al. [10]. They collected COCs from buffaloes and vitrified using either a conventional straw, open pulled straw, cryoloop, hemistraw or cryotop. Their results suggest that hemistraw, cryotop, and cryoloop are more suitable as cryo-device for vitrification of buffalo oocytes.

(C) 2020 Lifescience Global 
Vitrification requires the use of cryoprotectant solutions, which prevent ice crystal formation and increase viscosity at low temperatures. Several cryoprotectants, including ethylene glycol (EG), glycerol (GLY), dimethylsulfoxide (DMSO), propylene glycol (PG), and 1,2-propanediol (PROH), sucrose, etc. have been used in different combinations for vitrification of buffalo oocytes and embryos [11]. EG is an important cryoprotectant due to its higher penetrating ability with low toxicity [12]. EG and PG are equally effective in preventing cryodamage of buffalo oocytes [13]. Disaccharides are recently being used for the vitrification of oocytes in various species, including mouse [14], cattle [15], buffalo [16], and human [17, 18]. Effects of different sugars (i.e. glucose, sucrose, or a polysaccharide) as non-permeant cryoprotectants in vitrification media on in vitro maturation of vitrifiedwarmed immature (GV) porcine oocytes have been studied by Huang et al. [19]. They reported that sucrose treated oocytes had a higher maturation rate compared to oocytes vitrified in glucose supplemented cryoprotectant.

In principle, short exposure to a high concentration of cryoprotectants has been widely used to reduce cell injury. In contrast, Mukaida (2002) has reported a high survival rate of blastocysts vitrified with a combination of EG and DMSO [20]. The combination of EG and DMSO for the vitrification process provides a lower relative concentration and also causes lower toxicity. In fact, when DMSO penetrates the cell and combines with other cryoprotectants, it accelerates glass-forming and increases the permeability rate complementing each other. DMSO has been used for the vitrification of oocytes in many species, including buffalo [21] and cattle [22]. However, it has been reported that DMSO adversely affects the developmental processes of oocytes [23].

Polyvinylpyrrolidone (PVP), also known as povidone, is a water-soluble polymer of $\mathrm{N}$-vinyl-2pyrrolidone [24]. It has been used widely in pharmaceuticals, cosmetics, and food industries. It is used as a vehicle for drugs and a food additive. PVP has been used for intra-cytoplasmic sperm injection (ICSI) to increase the viscosity of sperm solution for easy handling of individual sperm in domestic animals and humans [25-30]. PVP prevents the adherence of oocytes to plastic and glass dishes. It has also been used in media for the in vitro growth of bovine oocytes [31]. PVP was used as a substitute for a serum for in vitro maturation of bovine [32]. Supplementation of PVP in EG and sucrose based vitrification solution resulted in an increased survival rate of bovine oocytes after vitrification and warming [33]. PVP is a nonpermeating cryoprotectant. It creates a smear around cells during vitrification and protects them from the cryodamage. It was reported that PVP protects the disruption of the zona of oocytes [34]. Supplementation of PVP in EG based vitrification media increased survivability of mouse oocytes [35]. PVP has a protective role in vitrification for survival and subsequent development of bovine oocytes [33]. However, so far, a few studies have been conducted to know the effect of PVP as a cryoprotectant for the vitrification of buffalo oocytes. This present study was aimed to examine the effect of replacing DMSO with PVP on vitrification solution for cryopreservation of buffalo oocytes.

\section{MATERIALS AND METHODS}

\section{Chemicals}

All chemicals were purchased from Sigma-Aldrich (St. Louis, MO) unless otherwise mentioned.

\section{Collection of Cumulus Oocyte Complexes (COCs)}

Buffalo ovaries were collected from a local slaughterhouse and transported to the laboratory in $0.9 \%$ normal saline. The ovaries were washed in Dulbecco's phosphate buffer saline (DPBS) solution supplemented with gentamycin sulfate $(50 \mathrm{mg} / \mathrm{mL})$ once and rinsed three times in DPBS. Visible antral follicles (4-6 $\mathrm{mm}$ in diameter) were aspirated using a 20-gauge needle attached to a $10 \mathrm{ml}$ syringe to collect COCs. The COCs were screened under a stereomicroscope and washed three times in TCM-199 (pH 7.4, Nissui Pharmaceutical, Tokyo, Japan) containing $0.85 \mathrm{mg} / \mathrm{mL} \quad \mathrm{NaHCO}_{3}, \quad 0.08 \mathrm{mg} / \mathrm{mL}$ gentamycin sulfate and $25 \mathrm{mM}$ HEPES in a plastic dish (No. 1008, Falcon, Becton Dickinson and Company, Franklin lakes, NJ, USA) for vitrification. COCs containing healthy oocytes (120-130 $\mu \mathrm{m}$ in diameters) were selected based on their morphological appearances (uniformly granulated cytoplasm surrounded by multilayered compact cumulus cells) for vitrification [36].

\section{Vitrification and Warming of Oocytes}

Vitrification of COCs was performed following the procedure of our previous reports $[37,38]$ with some modifications. Briefly, the basic solution was TCM-199 containing $2.5 \mathrm{mg} / \mathrm{mL}$ HEPES, $2.47 \mathrm{mg} / \mathrm{mL} \mathrm{Na-}$ HEPES, $0.35 \mathrm{mg} / \mathrm{mL} \mathrm{NaHCO}$, and $0.05 \mathrm{mg} / \mathrm{mL}$ 
gentamycin sulfate. The equilibration solution was TCM-199 containing $7.5 \%(\mathrm{v} / \mathrm{v})$ ethylene glycol (EG), $7.5 \%(\mathrm{v} / \mathrm{v})$ dimethyl sulfoxide (DMSO) and $20 \%$ fetal bovine serum (FBS). The vitrification solution consisted of $15 \%(\mathrm{v} / \mathrm{v}) \mathrm{EG}, 15 \%(\mathrm{v} / \mathrm{v}) \mathrm{DMSO}, 0.5 \mathrm{M}$ sucrose and $20 \%$ FBS in M-199 in control (0\% Polyvinylpyrrolidone; PVP). In other two groups DMSO was replaced with 5 or $10 \%$ PVP (molecular weight 360,000 ). The warming solution was $20 \%$ FBS, $0.5 \mathrm{M}$ sucrose in M-199 that contained 0,5 or $10 \%$ PVP depending on the PVP concentrations of the vitrification solution. The dilution solution was $20 \%$ FCS in M-199 containing 0,5 or $10 \%$ PVP. The washing solution contained $20 \%$ FCS in M199.

At first, COCs were treated with equilibration solution at room temperature for $5 \mathrm{~min}$ and transferred to a vitrification solution for $1 \mathrm{~min}$. Then, 3-5 COCs were loaded on the filmstrip of a cryotop (Kitazato Biopharma, Shizuoka, Japan). The surrounding solution was removed and immediately plunged into liquid nitrogen $\left(-196^{\circ} \mathrm{C}\right)$. After vitrification, the COCs were warmed in the thawing solution for $5 \mathrm{~min}$. Then the COCs were placed in a dilution solution for $5 \mathrm{~min}$. The COCs were washed in a washing solution for 5 min to remove the cryoprotectants. The COCs were evaluated for morphological quality as described by Gupta et al. with some modifications [36]. Briefly, COCs with multilayered compact cumulus cells and good integrity between oolemma and zona pellucida were classified as morphologically normal COCs. The COCs with normal morphology were subsequently used for in vitro maturation, and the rest were discarded from further experiments.

\section{In Vitro Maturation (IVM)}

The basic medium for oocyte maturation was TCM199 supplemented with $0.1 \mathrm{mg} / \mathrm{ml}$ sodium pyruvate, $0.08 \mathrm{mg} / \mathrm{ml}$ gentamycin sulfate, $5 \%(\mathrm{v} / \mathrm{v})$ FBS and 100 $\mathrm{ng} / \mathrm{ml}$ follicle-stimulating hormone (FSH; NIDDK, Washington, DC, USA) [39]. The vitrified and thawed COCs were washed three times in the IVM medium. COCs were placed in $100 \mu \mathrm{L}$ droplet of IVM medium in $35 \mathrm{~mm}$ Petri dish under mineral oil, and incubated at $38.5 \mathrm{C}, 5 \% \mathrm{CO}_{2}$ in humidified air for $24 \mathrm{hrs}$. After 24 hrs, oocytes were observed under the microscope for cumulus expansion. The assessment of cumulus cell expansion was carried out as described by Maruska et al. with some modifications [40]. Briefly, COCs with one or two layers expanded, one-half of the cumulus expanded, all layers expanded other than last layers of corona radiata, or all layers expanded, including corona radiate, were classified as expanded COCs. All of the COCs other than expanded COCs, such as COCs without cumulus expansion (no observable sign of cumulus expansion), were classified as non-expanded COCs. The oocytes were picked up from the droplets and washed in Dulbecco's phosphate-buffered saline (DPBS). The oocytes were denuded mechanically using a small-bore pipette with the help of $0.1 \%(\mathrm{w} / \mathrm{v})$ hyaluronidase. Oocytes were fixed in acid-alcohol (acetic acid: ethanol $=1: 3$ ) for two days, stained with aceto-glycerol (glycerol: acetic acid: water $=1: 1: 3$ ) and examined under a differential interference contrast (DIC) microscope (Olympus Inc., USA) for meiotic stages [39]. Oocytes were classified based on their chromosomal configuration following the previous report of Motlik et al. [41]. Oocytes showing cytoplasmic or nuclear abnormalities were considered degenerated.

\section{Statistical Analysis}

All data were subjected to one-way ANOVA, and the significance of difference among means was determined by Duncan's Multiple Range Test (DMRT). All statistical analyses were conducted using SPSS (IBM SPSS Statistics 22) software for Windows. Values of $P<0.05$ were considered significant.

\section{RESULTS}

\section{Effects of PVP on the Morphology of Vitrified Buffalo Oocytes}

The numbers of oocytes recovered after vitrification did not differ among the treatment groups (Table 1). However, the number of morphologically normal oocytes was significantly $(P<0.05)$ higher in $5 \%$ PVP than that of other groups. In a higher concentration $(10 \%)$ and without PVP oocytes underwent to various abnormal morphological changes, e.g., shrinkage of oocytes cytoplasm, denudation of oocytes and dissociation of cumulus cells, etc.

\section{Effects of PVP on In Vitro Maturation of Vitrified Buffalo Oocytes}

A proportion of vitrified oocytes treated with $5 \%$ PVP reached the MII stage while none of oocytes in 0or10\% PVP group progressed beyond Anaphase I and Ml stage, respectively (Table 1). The percentage of oocytes at the Ml stage was higher in 5\% PVP $(40 \%)$ than in other groups. The cumulus expansion in $5 \%$ PVP treated oocytes were also comparable with that in control group, although there were no significant 
Table 1: Effects of PVP on Morphology and in vitro Maturation of Vitrified Buffalo Oocytes

\begin{tabular}{|c|c|c|c|c|c|c|c|c|}
\hline \multirow{2}{*}{$\begin{array}{l}\text { Concentrations } \\
\text { of PVP (\%) }\end{array}$} & \multirow{2}{*}{$\begin{array}{c}\text { Numbers of } \\
\text { oocytes } \\
\text { examined }\end{array}$} & \multirow{2}{*}{$\begin{array}{c}\text { Recovered } \\
\text { after } \\
\text { vitrification } \\
(\%)\end{array}$} & \multirow{2}{*}{$\begin{array}{c}\text { Morphologically } \\
\text { normal oocytes } \\
(\%)\end{array}$} & \multirow{2}{*}{$\begin{array}{c}\text { Cumulus } \\
\text { expansion } \\
(\%)\end{array}$} & \multicolumn{4}{|c|}{$\begin{array}{c}\text { Numbers }(\%) \text { of oocytes at different stages } \\
\text { of meiotic division }\end{array}$} \\
\hline & & & & & MI & Al & $\mathrm{TI}$ & MII \\
\hline 0 & 24 & $20(83)$ & $8(40)^{b}$ & $20(83)$ & $4(20)$ & $0(0)$ & $0(0)$ & $0(0)$ \\
\hline 5 & 18 & $15(83)$ & $14(93)^{a}$ & $15(83)$ & $4(27)$ & $1(7)$ & $1(7)$ & $6(40)$ \\
\hline 10 & 21 & $14(67)$ & $4(28)^{b}$ & $14(67)$ & $0(0)$ & $0(0)$ & $0(0)$ & $0(0)$ \\
\hline
\end{tabular}

${ }^{\mathrm{a}-\mathrm{c}}$ Values with different superscripts in the same column differed $(P<0.05)$. Oocytes were subjected to in vitro maturation, followed by vitrification. Oocytes were classified as MI, Metaphase I; AI, Anaphase I; TI, Telophase I; MII, Metaphase II.
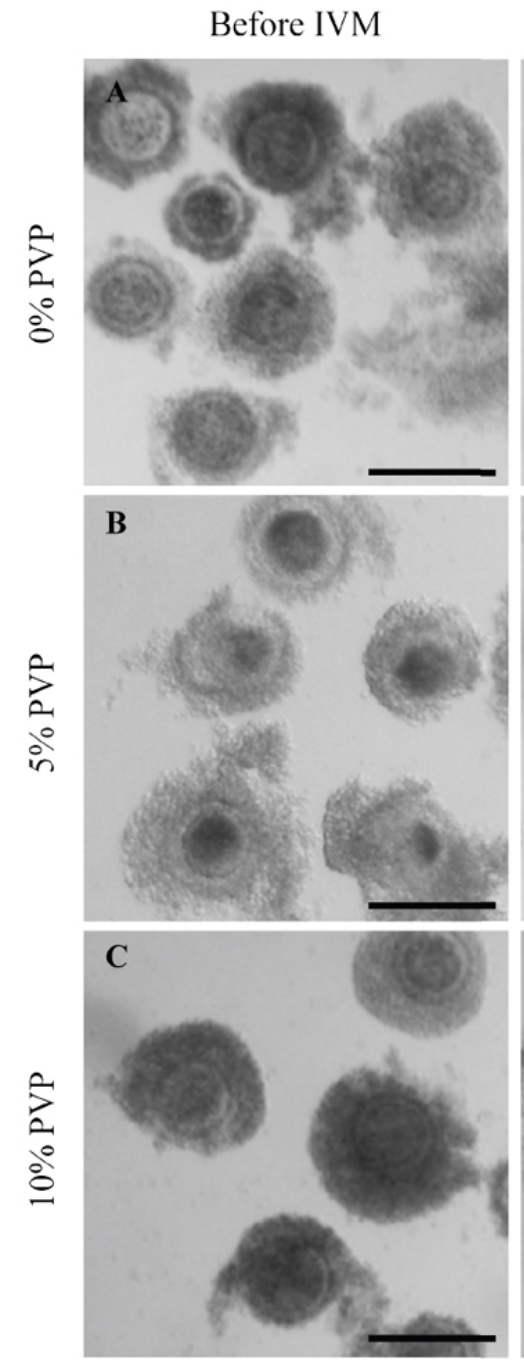

After IVM
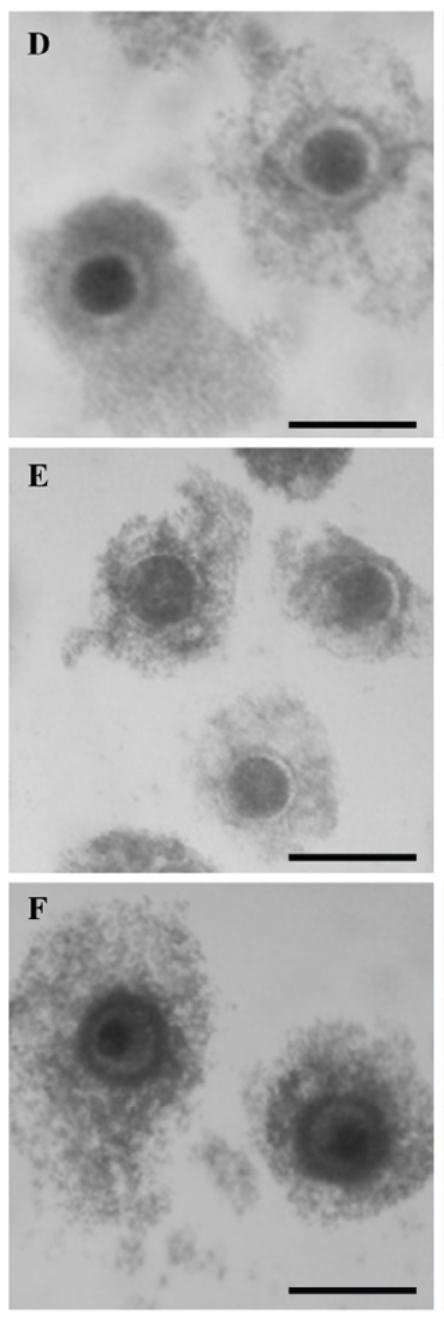
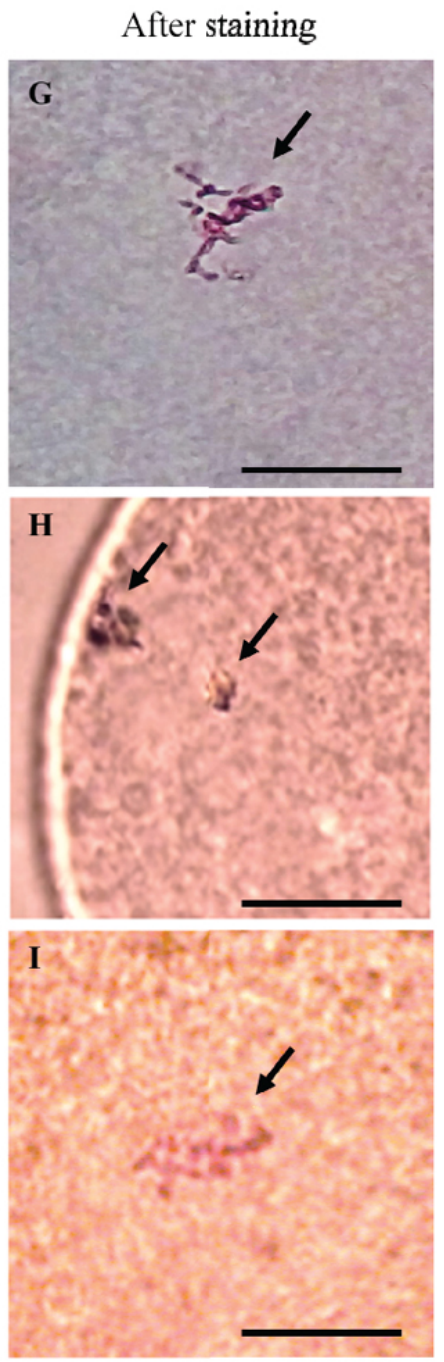

Figure 1: Vitrified oocytes (with different concentrations of PVP) before (A-C) and after (D-F) maturation. Chromosome morphologies of vitrified oocytes after culture (G-I). Scale bars represent $200 \mu \mathrm{m}$ (A-F) and $20 \mu \mathrm{m}$ (G-I). Arrows indicate chromosomes.

differences among the PVP treated groups (Table 2, Figure 1).

\section{DISCUSSION}

The present study showed that 5\% PVP treated vitrified oocytes reached the MII stage while oocytes in other groups ( $0 \%$ or $10 \%$ PVP) resumed meiosis but did not reached the MII stage. PVP is a macromolecule that prevents oocytes from cryoinjury. It has been added to cryopreservation solutions for embryos in many species [42]. Yang et al. investigated the effects of PVP concentrations in vitrification solution on the post-thaw survival and in vitro maturation of bovine 
oocytes [33]. Among the treatment groups, the survival rate of oocytes was higher in 5\% PVP than in $0 \%$ or $10 \%$ PVP. The rate of in vitro maturation was more elevated in $5 \%$ than the 10\% PVP group. In the slow freezing of bovine oocytes, 5\% PVP had a beneficial effect compared with 10 or $20 \%$ PVP [43]. On the other hand, Checura and Seidel (2007) reported the successful vitrification of bovine oocytes with 20 and $6 \%$ PVP [44]. Mouse embryo was successfully vitrified with supplementation of EG and sucrose as a cryoprotectant solution with $7.5 \%$ PVP [45].

Despite the protective effects, cryoprotectants impose toxicity to cells [45]. DMSO affects the organisation of the microtubule systems in mouse oocytes [23]. Cytoskeletal elements are implicated during the developmental process in oocytes [47]. It was reported that DMSO altered the microtubule organization of mouse oocytes [48]. DMSO caused progressive disassembly of the spindle that was demonstrated to be sensitive in chilling $[49,50]$. It lowered the critical protein content for microtubule assembly $[51,52]$. This may be the reason for the lower rate of meiotic progression in DMSO treated oocytes in this experiment. The present study showed that PVP could be a better replacer of DMSO in vitrification of buffalo oocytes. Previously it has been reported that PVP prevents zona pellucida of oocytes from cryodamage [53]. However, comparing the results in DMSO, PVP could not rescue buffalo oocytes from cryodamage as it was expected. In agreement with our results, it was reported that normal developmental competence of buffalo oocytes was compromised by vitrification with PVP [54].

PVP at a concentration of $5 \%$ increased morphologically normal COCs after vitrification than $0 \%$ and $10 \%$ of PVP. This indicated that PVP increased the survivability of oocytes during vitrification. PVP in the vitrification solution increased the survival rate of mouse oocytes after vitrification-warming [35]. Whittingham (1971) reported fruitful use of PVP for the cryopreservation of mouse 8 cell stage embryos and further early blastocysts [55]. When embryos were frozen at a temperature of $-79^{\circ} \mathrm{C}$ in a $7.5 \%$ PVP solution, the survival rate was $55-65 \%$. Damage to the zona pellucida after freezing and thawing in mouse embryos was accompanied by low survival rates of the embryo itself [56]. Since the survivability of oocytes and embryos during vitrification is largely depends on the zona pellucida and in this experiment, zona pellucida were examined to assess the morphologically normal oocytes. It is reasonable to conclude that PVP maintains the integrity of oolemma and zona pellucida, and cumulus cells and zona pellucida thereby increased morphologically normal COCs after vitrification.

It is thought that PVP is deleterious for the development of vitrified embryo [57]. It is toxic to kidney cells [45]. In the present study, a lower rate of meiotic progression was found in 10\% PVP treated oocytes than in $5 \%$ PVP group. This might be due to the deleterious effect of a higher concentration of PVP on oocyte maturation. This supports the previous report of Wang et al. (2013), where mouse oocytes were vitrified with $2 \%$ PVP combined with other cryoprotectants [35]. However, further study is necessary to elucidate the mechanisms involved in the deleterious effect of a higher concentration of PVP on oocytes and embryos.

In conclusion, PVP protects buffalo oocytes from cryoinjury and supports the meiotic progression of oocytes in vitro after vitrification and warming. PVP at a concentration of $5 \%$ maintains the normal morphology and promotes meiotic maturation of oocytes after vitrification and warming, whereas 10\% PVP exerts the toxic effects. Therefore, $5 \%$ of PVP could be used as a cryoprotectant for the vitrification of buffalo oocytes.

\section{CONFLICT OF INTEREST}

The authors declare that no conflict of interest could be perceived as prejudicing the research submitted impartiality.

\section{ACKNOWLEDGEMENTS}

We are thankful to Steve Clark, Senior Research Scientist, Agriculture Research \& Development, Victoria, Australia, for his critical suggestions for improvement of this manuscript.

\section{REFERENCES}

[1] Rahman SR, Islam MN, Harun-ur-Rashid M, Sarker NR Siddiki MS, Islam MZ, Islam MA. Buffalo milk yield, quality, and marketing in different agro-climatic districts of Bangladesh. J Buff Sci 2019; 8(3): 62-67. https://doi.org/10.6000/1927-520X.2019.08.03.2

[2] Vencato J, Badon T, Bedin S, Cogo P, Simonato M, Stelletta C. Biochemical and fatty acids composition of water buffalo (Bubalus bubalis) follicular fluid. J Buff Sci 2014; 3(3): 82-88. https://doi.org/10.6000/1927-520X.2014.03.03.3

[3] Totey SM, Pawshe $\mathrm{CH}$, Singh GP. In vitro maturation and fertilization of buffalo oocytes (Bubalus bubalis) effects of media, hormones and sera. Theriogenology 1993; 39: 11531171.

https://doi.org/10.1016/0093-691X(93)90014-V

[4] Gasparrini B. In vitro embryo production in buffalo species: state of the art. Theriogenology 2002; 57: 237-256. https://doi.org/10.1016/S0093-691X(01)00669-0 
[5] Berdugo-Gutiérrez JA, Echeverri JJ, Tarazona AM, LópezHerrera A. Differences of the fertility fotential between buffaloes (Bubalus bubalis) and cattle (Bos indicus): the role of antimullerian hormone (AMH). J Buff Sci 2017; 6: 74-80. https://doi.org/10.6000/1927-520X.2017.06.03.2

[6] Rall WF, Fahy GM. Ice-free cryopreservation of mouse embryos at $-196{ }^{\circ} \mathrm{C}$ by vitrification. Nature 1985 ; 313: $573-$ 575. https://doi.org/10.1038/313573a0

[7] Abdel-Ghani MA, El-Sherry TM, Abdelhafeez HH. Effect of growth differentiation factor-9 (GDF-9) on the progression of buffalo follicles in vitrified-warmed ovarian tissues. Reprod Dom Anim 2016; 51(5): 795-803. https://doi.org/10.1111/rda.12753

[8] Hufana-Duran D, Pedro PB, Venturina HV, Hufana RD, Salazar AL, Duran PG, Cruz LC. Post-warming hatching and birth of live calves following transfer of in vitro-derived vitrified water buffalo (Bubalus bubalis) embryos. Theriogenology 2004; 61(7-8): 1429-1439. https://doi.org/10.1016/j.theriogenology.2003.08.011

[9] BonDurant RH, Drost M, Zambrano-Varon J, Campanile G, Gasparrini B, Zicarelli L. Importation of in vitro-produced Bubalus bubalis embryos from Italy into the United States: A case report. Theriogenology $2007 ; 68(3): 454-460$. https://doi.org/10.1016/j.theriogenology.2007.05.049

[10] Mahesh YU, Gibence HR, Shivaji S, Rao BS. Effect of different cryo-devices on in vitro maturation and development of vitrified-warmed immature buffalo oocytes. Cryobiology 2017; 75: 106-116.

https://doi.org/10.1016/j.cryobiol.2017.01.004

[11] Parnpai R, Liang $Y$, Ketudat-Cairns M, Somfai T, Nagai T. Vitrification of buffalo oocytes and embryos. Theriogenology 2016; 86: 214-220. https://doi.org/10.1016/j.theriogenology.2016.04.034

[12] Shaw JM, Kuleshova LL, MacFarlane DR, Trounson AO. Vitrification properties of solutions of ethylene glycol in saline containing PVP, Ficoll, or dextran. Cryobiology 1997; 35: 219-229. https://doi.org/10.1006/cryo.1997.2043

[13] Purohit GN, Meena V, Solanki K. Morphological survival and subsequent in vitro maturation of denuded and cumulus compact bubaline oocytes cryopreserved by ultra rapid cooling. J Buff Sci 2012; 1(1): 78-83. https://doi.org/10.6000/1927-520X.2012.01.01.14

[14] Nakagata N. High survival rate of unfertilized mouse oocytes after vitrification. J Reprod Fertil 1989; 87: 479-483. https://doi.org/10.1530/jrf.0.0870479

[15] Marques CC, Santos-Silva C, Rodrigues C, Matos JE, Moura T, Baptista MC, Horta AE, Bessa RJ, Alves SP, Soveral G, Pereira RM. Bovine oocyte membrane permeability and cryosurvival: Effects of different cryoprotectants and calcium in the vitrification media. Cryobiology 2018; 81: 4-11. https://doi.org/10.1016/j.cryobiol.2018.03.003

[16] El-Shalofy AS, Moawad AR, Darwish GM, Ismail ST, Badawy $A B$, Badr MR. Effect of different vitrification solutions and cryodevices on viability and subsequent development of buffalo oocytes vitrified at the germinal vesicle (GV) stage. Cryobiology 2017; 74: 86-92.

https://doi.org/10.1016/j.cryobiol.2016.11.010

[17] Kuwayama M. Highly efficient vitrification for cryopreservation of human oocytes and embryos: The Cryotop method. Theriogenology 2007; 67: 73-80. https://doi.org/10.1016/j.theriogenology.2006.09.014

[18] Wright DL, Eroglu A, Toner M, Toth TL. Use of sugars in cryopreserving human oocytes. Reprod Biomed Online 2004; 9: 179-186. https://doi.org/10.1016/S1472-6483(10)62127-X

[19] Huang J, Li Q, Zhao R, Li W, Han Z, Chen X, Xiao B, Wu S, Jiang Z, Hu J, Liu L. Effect of sugars on maturation rate of vitrified-thawed immature porcine oocytes. Anim Reprod Sci 2008; 106: 25-35.

https://doi.org/10.1016/j.anireprosci.2007.03.023

[20] Mukaida T. Blastocyst cryopreservation: ultrarapid vitrification using cryoloop technique. Reprod Biomed Online 2002; 6: 221-225.

https://doi.org/10.1016/S1472-6483(10)61713-0

[21] Wani NA, Maurya SN, Misra AK, Saxena VB, Lakhchaura BD. Effect of cryoprotectants and their concentration on in vitro development of vitrified-warmed immature oocytes in buffalo (Bubalus bulalis). Theriogenology 2004; 61: 831-842. https://doi.org/10.1016/j.theriogenology.2003.06.002

[22] Vieira AD, Mezzalira A, Barbieri DP, Lehmkuhl RC, Rubin MI, Vajta G. Calves born after open pulled straw vitrification of immature bovine oocytes. Cryobiology 2002; 45: 91-94. https://doi.org/10.1016/S0011-2240(02)00109-8

[23] Vincent C, Pickering SJ, Johnson MH, Quick J. Dimethyl sulfoxide affects the organization of microfilaments in the mouse oocyte. Mol Reprod Dev 1990; 26: 227-235. https://doi.org/10.1002/mrd.1080260306

[24] Haaf F, Sanner A, Straub F. Polymers of N-vinylpyrrolidone: synthesis, characterization and uses. Polymer Journal. 1985 17(1): 143.

https://doi.org/10.1295/polymj.17.143

[25] Steirteghem AC, Nagy Joris H, Liu J, Staessen C, Smitz J, Wisanto A, Devroey P. High fertilization and implantation rates after intracytoplasmic sperm injection. Hum Reprod 1993; 8: 1061-1066. https://doi.org/10.1093/oxfordjournals.humrep.a138192

[26] Kimura Y, Yanagimachi R. Intracytoplasmic sperm injection in the mouse. Biol Reprod 1995; 52: 709-720. https://doi.org/10.1095/biolreprod52.4.709

[27] Hamano K, Li X, Funauchi K, Furudate M, Minato Y. Gender preselection in cattle with intracytoplasmically injected, flow cytometrically sorted sperm heads. Biol Reprod 1999; 60: 1194-1197.

https://doi.org/10.1095/biolreprod60.5.1194

[28] Catt SL, Catt JW, Gomez MC, Maxwell WM, Evans G. Birth of a male lamb derived from an in vitro matured oocyte fertilised by intracytoplasmic injection of a single presumptive male sperm. Vet Rec 1996; 139: 494-495.

https://doi.org/10.1136/vr.139.20.494

[29] Cochran R, Meintjes M, Reggio B, Hylan D, Carter J, Pinto C Paccamonti D, Godke RA. Live foals produced from sperm-injected oocytes derived from pregnant mares. J Equine Vet Sci 1998; 18: 736-740. https://doi.org/10.1016/S0737-0806(98)80504-2

[30] Martin MJ. Development of in vivo matured porcine oocytes following intracytoplasmic sperm injection. Biol Reprod 2000; 63: 109-112.

https://doi.org/10.1095/biolreprod63.1.109

[31] Hirao Y, Itoh T, Shimizu M, Iga K, Aoyagi K, Kobayashi M, Kacchi M, Hoshi $\mathrm{H}$, Takenouchi $\mathrm{N}$. In vitro growth and development of bovine oocyte-granulosa cell complexes on the flat substratum: effects of high polyvinylpyrrolidone concentration in culture medium. Biol Reprod 2004; 70: 8391.

https://doi.org/10.1095/biolreprod.103.021238

[32] Chung JT, Tosca L, Huang TH, Xu L, Niwa K, Chian RC. Effect of polyvinylpyrrolidone on bovine oocyte maturation in vitro and subsequent fertilization and embryonic development. Reprod Biomed Online 2007; 15: 198-207. https://doi.org/10.1016/S1472-6483(10)60709-2

[33] Yang BC, Im GS, Chang WK, Lee YK, Oh SJ, Jin DI, Im KS, Lee CK. Survival and in vitro development of immature bovine oocytes cryopreserved by vitrification. Asian-australas J Anim Sci 2002; 16(1): 23-28. https://doi.org/10.5713/ajas.2003.23 
[34] Titterington JL, Robinson J, Killick SR, Hay DM. Fertilization and early embryology: Synthetic and biological macromolecules: protection of mouse embryos during cryopreservation by vitrification. Hum Reprod 1995; 10: 649653.

https://doi.org/10.1093/oxfordjournals.humrep.a136004

[35] Wang Y, Okitsu O, Zhao XM, Sun Y, Di W, Chian RC. The effect of minimal concentration of ethylene glycol (EG) combined with polyvinylpyrrolidone (PVP) on mouse oocyte survival and subsequent embryonic development following vitrification. J Assist Reprod Genet 2013; 31: 55-63. https://doi.org/10.1007/s10815-013-0136-5

[36] Gupta MK, Uhm SJ, Lee HT. Cryopreservation of immature and in vitro matured porcine oocytes by solid surface vitrification. Theriogenology 2007; 67(2): 238-248. https://doi.org/10.1016/j.theriogenology.2006.07.015

[37] Moniruzzaman M, Bao RM, Taketsuru $H$, Miyano $T$. Development of vitrified porcine primordial follicles in xenografts. Theriogenology 2009; 72: 280-288. https://doi.org/10.1016/j.theriogenology.2009.01.024

[38] Bao RM, Yamasaka E, Moniruzzaman M, Hamawaki A, Yoshikawa M, Miyano T. Development of vitrified bovine secondary and primordial follicles in xenografts. Theriogenology 2010; 74: 817-827. https://doi.org/10.1016/j.theriogenology.2010.04.006

[39] Islam MN, Md Hasanur Alam, Khatun A, Akter I, Modak AK, Hashem MA, Moniruzzaman M. Effects of stem cell factor on in vitro growth of buffalo oocytes. Theriogenology 2020; 142 : 114-119. https://doi.org/10.1016/j.theriogenology.2019.09.044

[40] Maruska DV, Lorraine Leibfried M, First NL. Role of calcium and the calcium-calmodulin complex in resumption of meiosis, cumulus expansion, viability, and hyaluronidase sensitivity of bovine cumulus-oocyte complexes. Biol Reprod 1984; 31(1): 1-6. https://doi.org/10.1095/biolreprod31.1.1

[41] Motlik J, Johnsen KHH, Fulka J. Breakdown of the germinal vesicle in bovine oocytes cultivated in vitro. J Exp Zool 1978; 205: 377-83.

https://doi.org/10.1002/jez.1402050306

[42] Kuleshova LL, Shaw JM, Trounson AO. Studies on replacing most of the penetrating cryoprotectant by polymers for embryo cryopreservation. Cryobiology 2001; 43: 21-31. https://doi.org/10.1006/cryo.2001.2335

[43] Suzuki T, Boediono A, Takagi M, Saha S, Sumantri C. Fertilization and development of frozen-thawed germinal vesicle bovine oocytes by a one-step dilution method in vitro. Cryobiology 1996; 33: 515-524.

https://doi.org/10.1006/cryo.1996.0055

[44] Checura CM, Seidel GE Jr. Effect of macromolecules in solutions for vitrification of mature bovine oocytes. Theriogenology 2007; 67: 919-930. https://doi.org/10.1016/j.theriogenology.2006.09.044

[45] Kim C, Yong $H$, Lee G, Cho J. Effect of the polyvinylpyrrolidone concentration of cryoprotectant on mouse embryo development and production of pups: $7.5 \%$ of
PVP is beneficial for in vitro and in vivo development of frozen-thawed mouse embryos. J Reprod Dev 2008; 54: 250253.

https://doi.org/10.1262/jrd.19185

[46] Fahy GM, Lilley TH, Linsdell H, Douglas MS, Meryman HT. Cryoprotectant toxicity and cryoprotectant toxicity reduction in search of molecular mechanisms. Cryobiology 1990; 27: 247-268. https://doi.org/10.1016/0011-2240(90)90025-Y

[47] Maro B, Howlett SK, Houliston E. Cytoskeletal dynamics in the mouse egg. J Cell Sci Suppl 1986; 5: 343-359. https://doi.org/10.1242/jcs.1986.Supplement_5.22

[48] Johnson MH, Pickering SJ. The effect of dimethyl sulfoxyde on the microtubular system of the mouse oocyte. Development 1987; 100: 313-324.

[49] Magistrini M, Szöllösi D. Effects of cold and of isopropyl-Nphenylcarbamate on the second meiotic spindle of mouse oocytes. Eur J Cell Biol 1980; 22: 699-707.

[50] Pickering SJ, Johnson MH. The influence of cooling on the organization of the meiotic spindle of the mouse oocyte. Hum Reprod 1987; 2: 207-216. https://doi.org/10.1093/oxfordjournals. humrep.a136516

[51] Lee James C, and Serge N Timasheff. In vitro reconstitution of calf brain microtubules: effects of solution variables. Biochemistry 1977; 16: 1754-1764. https://doi.org/10.1021/bi00627a037

[52] Algaier Joseph and Richard H. Himes. The effects of dimethyl sulfoxide on the kinetics of tubulin assembly. Biochim Biophys Acta 1988; 954: 235-243. https://doi.org/10.1016/0167-4838(88)90078-7

[53] Dumoulin JC, Bergers-Janssen JM, Pieters MH, Enginsu ME, Geraedts JP, Evers JL. The protective effects of polymers in the cryopreservation of human and mouse zonae pellucidae and embryos. Fertil Steril 1994; 62: 793-798. https://doi.org/10.1016/S0015-0282(16)57006-X

[54] Liang YY, Srirattana K, Phermthai T, Somfai T, Nagai T, Parnpai R. Effects of vitrification cryoprotectant treatment and cooling method on the viability and development of buffalo oocytes after intracytoplasmic sperm injection. Cryobiology 2012; 65(2): 151-156. https://doi.org/10.1016/j.cryobiol.2012.04.006

[55] Whittingham DG. Survival of mouse embryos after freezing and thawing. Nature 1971; 233(5315): 125-126. https://doi.org/10.1038/233125a0

[56] Dumoulin JC, Bergers-Janssen JM, Pieters MH, Enginsu ME, Geraedts JP, Evers JL. The protective effects of polymers in the cryopreservation of human and mouse zonae pellucidae and embryos. Fertil Steril 1994; 62(4): 793-798. https://doi.org/10.1016/S0015-0282(16)57006-X

[57] Friedler S, Giudice LC, Lamb EJ. Cryopreservation of embryos and ova. Fertil Steril 1988; 49: 743-64. https://doi.org/10.1016/S0015-0282(16)59879-3

\section{DOI: https://doi.org/10.6000/1927-520X.2020.09.16}

\section{(c) 2020 Bari et al.; Licensee Lifescience Global.}

This is an open access article licensed under the terms of the Creative Commons Attribution Non-Commercial License (http://creativecommons.org/licenses/by-nc/3.0/) which permits unrestricted, non-commercial use, distribution and reproduction in any medium, provided the work is properly cited. 